\title{
EDUCATIONAL VALUES IN THE NOVEL ENTITLED NEGERI 5 MENARA BY A. FUADI
}

\author{
By \\ Ramlah $^{1}$, M. Amir P' ${ }^{2}$, Indriati Lewa ${ }^{3}$ \\ ${ }^{1,2,3}$ Cultural Studies Faculty, Hasanuddin University \\ Email: ${ }^{1}$ ramlahnorma333@ gmail.com, ${ }^{2}$ amirppatu@ymail.com, ${ }^{3}$ inriatilewa@yahoo.com
}

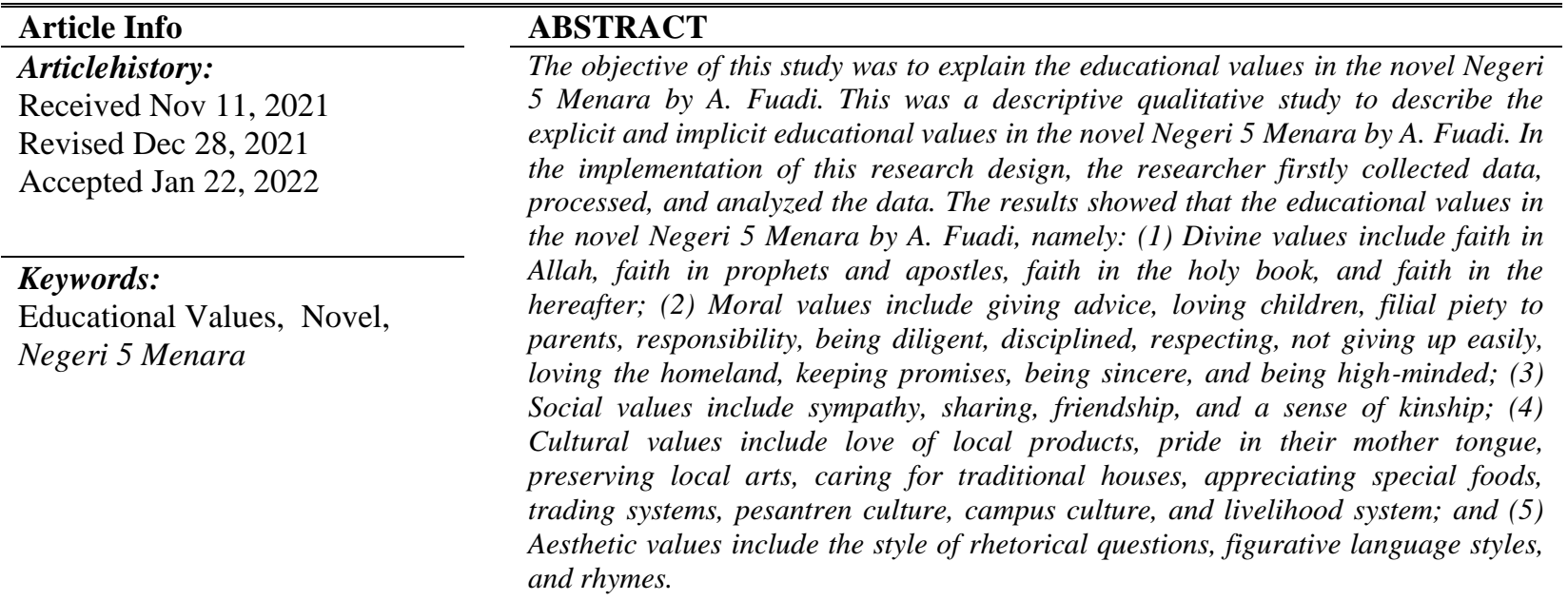

Thisisan open accessarticleundertheCC BY-SAlicense.

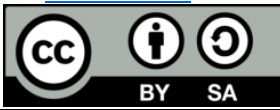

CorrespondingAuthor:

Ramlah

Cultural Studies Faculty, Hasanuddin University

Email: ramlahnorma333@gmail.com

\section{INTRODUCTION}

One of the literary genres that are commonly found in society, especially the Indonesian people, is novel. It is defined as a long prose essay that contains a series of stories from a person's life and those around him by highlighting the character and nature of each actor. A novel is a type of literary work that contains cultural, social, moral, and educational values.

The novel is one type of literary work in the form of a narrative and continuous character characterized by the action and reaction between the characters, especially between the antagonist and the protagonist (Semi, 1988:36). The antagonist and protagonist are always presented in the novel. This will raise various problems (conflicts) that cause tension and curiosity for the audience of the novel itself. The stories that are built will relate to each other. Therefore, it is logical to state that the novel is a work that requires high concentration in its production. On this basis, this study uses the novel as the object of research.

The novel that is used as a source of study data in this research is a novel by A. Fuadi entitled Negeri 5 Menara. The novel, which is inspired by a true story, tells the story of the life journey of six students from six different regions. They studied at PondokMadani (PM) Ponorogo, East Java. These six students were far from home and have succeeded in realizing their dream. Due to the differences in the areas of origin of the six novel characters, it is hoped that this will enrich the results of this research study.

The first novel in A. Fuadi's trilogy is appointed as the focus of this research study because it is different from the other two titles in this trilogy. The difference is that the novel Negeri 5 Menara is still full of wisdom values.

In addition, this novel has many advantages, for example, it is loaded with motivation and inspiration. In describing the story of the characters, the author instils noble values so that readers can enjoy them. In addition, 
some of the stories also include tips for success in which this can foster character values in life. These advantages are the main reasons why A. Fuadi's novel will be studied, especially concerning educational values which are expected to shape character for the readers.

Value is absurd, the level, quality, or essence contained in something has meaning for human life. Values in general are tremendously broad. Education is coupled with the word value to limit the existence of broad values. Educational values are more inclined to teachings that are targeted in realizing educational goals.

Because value is an abstract object, the results of this study try to describe its abstractness so that the values contained in the novel above can be known in depth. In this description, various steps or approaches can be taken, for example in terms of semantics, pragmatics, or hermeneutics.

In addition to the author who made value as a message to be conveyed in a literary work, there are various techniques for delivering the message. Some use direct techniques; while others use indirect techniques. This gives rise to an explicit meaning and an implied meaning so that in finding value in a literary work, it is not optimal if it is only read. It requires in-depth assessment and the right approach.

In literary studies, many ways can be used to analyze literary works. One of them is through a hermeneutic approach. Hermeneutics is widely used in text research in almost all scientific disciplines, including literature. In this study, the approach used was Paul Ricoeur's hermeneutic approach. Paul Ricoeur views the text as an independent unit. It is not influenced by the author and things outside the text itself, but it only lies in the interpretation.

\section{METHODS}

This study is library research better known as library research. Literature research is research that makes library materials such as books, scientific magazines, and other documents that can be used as a reference source in this research (Hadi, 2004: 9)

This research used a qualitative descriptive research design. The design of this study required the researcher to explain the educational values contained in the novel Negeri 5 Menara by A. Fuadi. In the application of this research design, the researcher first collected data, processed, and analyzed the data.

Based on the research objectives, the data collected in this study were data and information in the form of educational values contained in the novel Negeri 5 Menara by A. Fuadi. Therefore, to collect the required data and information, several data collection techniques were used, namely reading, documentation, and recording techniques.

The reading technique is the most important in this research because the object of the research is a written work. Difficult data cannot even be generated without going through the reading process. Reading is done by giving attention that is focused on the object (Ratna, 2010: 245). Reading technique, in this case, means that the researcher reads the literature and the main data source of the research, namely the novel entitled Negeri 5 Menara by A. Fuadi.

This technique is used to collect written data in the novel Negeri 5 Menara by A. Fuadi. The data were analyzed by selecting and sorting the educational values in the novel. The reading results that describe the value of education in the form of sentences or paragraphs used in the novel Negeri 5 Menara by A. Fuadi were recorded in the form of classification. The collected data was then analyzed by using Paul Ricoeur's hermeneutic approach.

\section{RESULTS AND DISCUSSION}

After observing the novel Negeri 5 Menara, written by A. Fuadi, the researcher found that it had educational values. These educational values were described as follows:

a. Divinity values include faith in Allah, faith in Allah's prophets and messengers, faith in the holy book, and faith in the hereafter.

b. Moral values include giving advice, loving children, filial piety, being responsible, being diligent, disciplined, respecting each other, not giving up easily, loving the homeland, keeping promises, being sincere, and being high-minded.

c. Social values include sympathy, sharing, friendship, and a sense of kinship.

d. Cultural values include love for local products, pride in the mother tongue, preserving local arts, caring for traditional houses, appreciating typical food, trading system, campus culture, pesantren culture, and livelihoods.

e. Aesthetic values include rhetorical language styles, figurative language styles, and rhymes.

This study expressed contextual problems so that awareness is needed to digest the meaning of the messages in the novel quotes. Therefore, the researcher would like to explain several points related to the approach used, namely Paul Ricoeur's hermeneutics.

First, Paul Ricoeur's hermeneutics views the text as not tied to the author's intention as in an expressive approach. The text belongs to the reader. Therefore, there may be many interpretations based on the number of 
International Journal of Social Science (IJSS)

Vol.1 Issue.5 February 2022, pp: 717-722

ISSN: 2798-3463 (Printed) | 2798-4079 (Online)

DOI: https://doi.org/10.53625/ijss.v1i5.1315

readers. This will create a rich interpretation that appears in interpreting a text. Second, Paul Ricoeur's hermeneutics applies three steps of meaning interpretation, namely (1) symbolic step, namely understanding symbols of events and meanings; (2) giving the meaning of the symbol, namely realizing connecting events with reality; and (3) the philosophical step, which is the thinking stage which means that the interpreter only deals with the substance of the text. These three steps are used to determine the educational value contained in the novel Negeri 5 Menara by A. Fuadi. The values are described in the following discussion.

\section{a. Divine Education Values}

\section{1) Faith in Allah}

The quote on page 197 of the third paragraph of the novel Negeri 5 Menara reflects the faith value in God. Humility is generally done by humans when they feel they are nothing or feel they cannot do anything. In the quote above, the main character of the novel is in one of these conditions. He will face the test and feel not ready. He also makes prayer as a last resort to escape from his condition.

This is a sign that the novel Negeri 5 Menara contains the value of faith in God. It is one form of faith in God in the novel. There is no other reason that can make people wake up to pray in the middle of the night other than faith. The faith described in the quote above causes the main character in the novel to complain about his anxiety to the Creator. It focuses on God and eliminates other than Him. At a time like this, there is no greater power than God. No one can help other than help from Allah, the name of God who is called the main character in the quote above.

\section{2) Faith in Allah's Holy Book}

The quote on page 253 paragraph seven of the novel of Negeri 5 Menara reflects the value of faith in Allah's Holy Book. This quote takes the essence of a verse in the Qur'an, namely Surah Az Zariyat verse 56 which means And I (Allah) created not the jinns and humans except they should worship Me (Alone) (Departemen Agama RI, 2006: 756). The reason humans were created and sent down to the world is to devote themselves or to serve themselves to Allah.

This quote is spoken with a belief in the holy book of the Quran. There is no doubt in the Quran. Every Muslim must practise all the commands and avoid all the prohibitions in the Qur'an. As a statement that often appears, namely sami'nawaatho' $\mathrm{Na}$. This statement can be interpreted as we hear and we obey.

\section{3) Faith in the Hereafter}

The quote from page 190 of paragraph one in the novel of Negeri 5 Menara reflects the value of faith in the Hereafter. Faith in the hereafter is one of the points of the pillars of faith adopted by Muslims. The hereafter is also believed by some religions outside of Islam. Especially in Islam, the hereafter is also known as the Day of Judgment. Judgment Day is the end of worldly life. The day of death and the day of resurrection after death. People who have died will be brought back to life to account for their actions.

This is a value that can be used as a lesson so that every religious community prepares themselves by believing at the end of the world. If the hereafter is believed, beliefs about death and the hereafter will be born so that people will compete to prepare themselves, even competing to achieve the title of martyr.

\section{b. Moral Education Value}

1) Giving Advice

The quote on page 219 paragraph three of the novel Negeri 5 Menara reflects the value of giving advice. Advising the teachings of Islam can be categorized as an obligation. This is based on the verse in the Qur'an, namely Surah Al Maidah verse 2. This verse explains that every creature, especially humans, help each other in goodness, and piety and prohibits humans from helping in matters of sin and enmity.

\section{2) Loving Children}

The quote from pages 10-11 of the fourth paragraph of the novel Negeri 5 Menara reflects the value of loving children. Children for parents are a responsibility imposed by God. Even in the life of the state, the responsibilities of parents to children are regulated by law. Article 26 paragraph 1 of Law 35/2014 regulates the obligations of parents towards their children.

Parents who carry out their responsibilities will indirectly have an impact on their children. Children immediately have a sense of inadequacy, even against the will of parents sometimes a child feels unable. However, parents also need to think carefully so that the will of the child does not seem forced.

\section{3) Be Filial to Parents}

The quote from the first 11 pages of the novel Negeri 5 Menara reflects the value of filial piety to parents. In each region, the meaning of mother varies. However, mothers have the highest position in Islam. This is based on a hadith narrated by Imam Bukhari. This hadith mentions the mother's name three times and the father's name once to the state where a child is devoted. 
This causes the expression of heaven on the soles of the mother's feet to be not an exaggeration. The sacrifice of a mother for her child is enormous. From in the womb to an unknown extent, the mother's sacrifice never stops. Mother is approximately nine months pregnant. She then gambled with the grim reaper during childbirth, then breastfed and so on. Based on that sacrifice, filial piety is an obligation for every child.

\section{4) Being Responsible}

The quote on page 81 of the third paragraph of the novel Negeri 5 Menara reflects the value of responsibility. Someone who is taught to always depend on himself will be trained to always be confident. As the steps of meaning above, it can be concluded that nafsi contains two contradictory meanings. One means good, the other means not good. Nafsi which means less good is selfish, while what means good is independent, confident.

In the world of education, especially Islamic boarding schools, being independent and confident is an educational value that must always be instilled in students. However, self-confidence must also be controlled by always presenting the name of God at every opportunity. In this way, it is hoped that a sense of responsibility will emerge.

Someone who learns independently always learns a sense of responsibility. Responsibility is a person's awareness of the obligation to be responsible for all the consequences of something he has done. If something goes wrong, a person must not run and must be willing to take the risk for his actions.

\section{5) Being Diligent}

The quote on page 193 of the third paragraph of the novel Negeri 5 Menara reflects the value of being diligent. The value of diligent moral education needs to be instilled in every generation. Diligent is an active behaviour that leads to a goal. Diligence is also a level of efficiency in studying or working. Especially in the world of education, being diligent prefers to be diligent in studying. Learning is not all interesting for every individual.

The words of the Prophet Muhammad emphasize how important it is for people to be diligent in studying. Science in the world of education is identical to books. This is why we have long heard the adage that books are the window of knowledge. Students of knowledge should be friendly with books because in books knowledge is found. This is still relevant to today's life even though it has begun to be eroded by the development of science.

\section{6) Being Discipline}

The quote on page 92 of the third paragraph of the novel Negeri 5 Menara reflects the value of discipline. The core value contained in this quote is that the character Baso teaches discipline to other characters and indirectly to readers. Discipline implies obedience, not making many additional movements in pursuit of the target to be achieved.

Discipline is closely related to respecting time such as the use of the clause providing time in the quote above. Time in the teachings of Islam is something great so that Allah swears on the name of time in Surah Al-Asr. This Surah invites believers to always value time. It is not into procrastinating because procrastination is a big loss.

\section{7) Respecting Others}

The quote from page 93 of the fifth paragraph of the novel Negeri 5 Menara reflects the value of respecting others. Respecting others in the quote above can be seen from the character's behaviour. The value of moral education is very closely related to the Indonesian people who adhere to the Pancasila ideology. As creatures created by Allah, humans are required to respect each other, respect each other regardless of differences. This is implied in the second principle of Pancasila, namely just and civilized humanity.

The second precept of Pancasila recognizes the existence of creatures called humans with all the rights and obligations of humans towards other humans. This precept shows the existence of an attachment between human identity and human values. That is, everyone must respect each other, value each other, and love each other even though the gap between differences is very wide.

The precepts of these two Pancasila also contain the values of justice and civility. Justice shows a broad sense of love for fellow human beings while civility shows the highest degree of the human being as a creature created by God. In the life of the nation and state, Pancasila requires Indonesian people to prioritize noble etiquette in treating others.

\section{8) Being Tough}

The quote from page 199 of the second paragraph of the novel Negeri 5 Menara reflects the value of never giving up. Never giving up can be anonymized with the term despair. In the teachings of Islam, giving up is prohibited. The verse of the Qur'an emphatically states that those who despair are disbelievers. This is written in Surah Yusuf verse 87. This verse implies the value of never giving up moral education. Everything that has been planned and targeted becomes an obligation to be fulfilled as long as the plans and targets do not come out of Islamic 
International Journal of Social Science (IJSS)

Vol.1 Issue.5 February 2022, pp: 717-722

ISSN: 2798-3463 (Printed) | 2798-4079 (Online)

DOI: https://doi.org/10.53625/ijss.v1i5.1315

values. Even the word of God above gives a hard line that people who easily give up are classified as unbelievers. This implies that everything takes effort and always expects a gift from Allah.

c. Social Education Value

\section{1) Being Sympathetic}

The quote from page 363 of the seventh paragraph of the novel Negeri 5 Menara reflects the value of sympathy. Sharing the suffering or pleasure of others is the essence of the quote above. A friend who faces a problem, the other characters also feel it even though indirectly the characters have nothing to do with the problem faced by the character. This is still relevant to today's life it must always be maintained.

However, recently, the value of social education about sympathy is starting to erode, especially in urban life. Individualism in urban society is extremely high so sympathy for others decreases by itself. However, in rural communities, this value is still maintained even though it has been eroded along with technological developments.

2) Sharing

The quote on page 270 of the fifth paragraph of the novel Negeri 5 Menara reflects the value of sharing. Every religion guides its people to always spread goodness wherever they are. One of the virtues among many virtues is sharing. Sharing is giving something to people who need a helping hand. Sharing in the Islamic concept is known as alms. However, alms are giving something to the poor who are entitled to receive it, apart from zakat and zakat fitrah according to the ability of the giver. Sharing is also explained in the Qur'an surah Al Talaq verse 7.

\section{3) Being Friendly}

The quote from page 223 of the first paragraph of the novel Negeri 5 Menara reflects the value of friendship. This quote describes the friendly feeling of the movements of other characters told by the main character. Said, who is described as having concrete hands, is always open to any helping hand, especially the main character. The value in this quote illustrates that no matter how hard life is, we must always smile.

In addition to smiling, a sense of friendship is also depicted by using the composition of open arms. Helping, being generous, and being friendly are values that must be instilled in every human being. Open arms are essentially an all-embracing position. The essence of open arms leads to friendship. Silaturahmi(brotherhood) is one of the morals taught by the Prophet Muhammad to always maintain the friendship.

\section{d. Cultural Education Value}

1) Loving Local Product

The quote from the first 6 paragraphs of the novel Negeri 5 Menara reflects the value of love for local products. As a society belonging to the Malay family, the values of politeness, ethics, and aesthetics are certainly never separated from doing something, including dressing. Clothing can generally reflect a person's personality. People who dress covertly are generally considered more ethical than people who dress openly. This happens naturally in life that adheres to eastern culture.

However, the eastern principle has begun to be colonized by western culture. One of the reasons for this is the development of technology and information. Through technology and information, people can see more broadly the life of the outside world. From seeing this activity, people finally started to try and follow it without paying attention to eastern ethics. Therefore, the value of loving local products needs to be instilled so that ethics and aesthetics are maintained.

\section{2) Caring for Traditional House}

The quote from page 24 of the fourth paragraph of the novel Negeri 5 Menara reflects the value of caring for a traditional house. In Indonesia, it is known that each region has a characteristic in the form of a traditional house. In each province, traditional houses are the hallmark of each. It is as if a traditional house is paired with traditional clothes, traditional weapons, and all other tribal attributes. This traditional house reflects the local wisdom of the people in the area.

RumahGadang and RumahJoglo are two different traditional houses. Although different, these two types of traditional houses are built based on their respective philosophies. This philosophical meaning is the essence of the value of caring for the traditional house contained in the novel Negeri 5 Menara.

\section{e. Aesthetic Education Value \\ 1) Rhetorical Language Style}

The quote from page 211 of the second paragraph of the novel Negeri 5 Menara reflects the value of rhetorical style. Philosophically, the novel quote above basically talks about a problem that hasn't happened yet. Something that has not happened is widely known as the future. The novel character in the quote above is imagining. The main character and several other characters are often joking under a tower. They often make the base of the tower a place to dream. 
The dream here is not a flower of sleep but is identified with wishful thinking, ideals, or efforts to face the future. This teaches that everyone needs to plan for their future success. Every individual needs to aspire and strive to pursue his goals from an early age.

Even so, any plan must still be based on the line of fate. Plans require the blessing of the Owner of the Universe. That is, the future needs to be carefully planned, but if the results are far from the plan, then each individual should not feel disappointed because it has been arranged by the Almighty.

\section{2) Figurative Language Style}

The quote from page 368 of the second paragraph of the novel Negeri 5 Menara reflects the aesthetic value of figurative language style. Losing a friend is painful. Be it lost due to betrayal or loss due to death, pain is still a certainty. The quote above has an aesthetic meaning because it uses a parable language style.

The main character assumes that he is the jaw while his friends are the molars. If one of the friends is missing, it means that one of the molars is pulled out. Due to the extraction of the molars, the jaw will be tormented in carrying out some of its functions. Thus, the author uses figurative language as an aesthetic value in this novel quote.

3) Pantun

The quote from page 393 of the eighth paragraph of the novel of Negeri 5 Menara reflects the aesthetic value of the rhyme. The short rhyme above contains a beautiful and noble value. The point that KiaiRais is willing to convey is the importance of studying. Knowledge will elevate the degree for those who have it. This is written in the Qur'an Surah Al Mujadilah verse 11.

Education is tremendously important in the life of this world and the hereafter. There will be a separate gap created between educated people and uneducated people. People with low education are identified with odd jobs, while people with high education are identified with office jobs. This is the majority of things even though there are a few that are not like that.

The advice in this short poem is still very relevant to today's life. It will always be relevant to any time or era because it is contained in the holy book. Especially nowadays, it is very easy to find the content of this short rhyme. Everywhere, people with higher education will be like the durians needed by many people, while those with low education are like the noni fruit which smells rotten.

\section{CONCLUSION}

Based on the results of the research in this paper, the authors conclude that the novel Negeri 5 Menara by A. Fuadi contains educational values, which are related to divinity, moral education, social education, cultural education, and aesthetic education. To produce learning outcomes with attitude, then these educational values can be implemented in literary learning, especially in learning drama texts in class VIII students of MTs Negeri Pangkep. Students' understanding of the educational value obtained through learning in schools can produce positive attitudes and behaviours.

\section{REFERENCE}

[1] Departemen Agama RI. 2006. Al-Qur'an dan Terjemahannya. Jakarta: CV Pustaka Agung Harapan.

[2] Fuadi, Ahmad. 2009. Negeri 5 Menara. Jakarta: Gramedia

[3] Hadi, Sutrisno. 2004. Metodologi Research 1. Yogyakarta: Andi Offset.

[4] Ratna, Nyoman Kutha. 2010. MetodologiPenelitian: Kajian Budaya dan IlmuSosialHumaniora pada Umumnya. Pustaka Pelajar: Yogyakarta.

[5] Semi, Atar. 1988. Kritik Sastra. Bandung: Angkasa. 